\title{
Silica Sulfuric Acid as an Efficient and Reusable Reagent for Crossed-Aldol Condensation of Ketones with Aromatic Aldehydes under Solvent-Free Conditions
}

\author{
Peyman Salehi ${ }^{*, a}$, Minoo Dabiri $^{b}$, Mohammad Ali Zolfigol ${ }^{c}$ and Mohammad Ali Bodaghi Fard ${ }^{b}$ \\ ${ }^{a}$ Department of Phytochemistry, Aromatic and Medicinal Plants and Drug Research Institute, Shahid Beheshti \\ University, Evin, P.O.Box 19835-389, Tehran, Iran \\ ${ }^{b}$ Department of Chemistry, Faculty of Science, Shahid Beheshti University, Evin, Tehran 1983963113, Iran \\ ${ }^{c}$ Department of Chemistry, Faculty of Science, Bu-Ali Sina University, Hamadan 65174, Iran
}

\begin{abstract}
Aldeídos aromáticos sofrem condensação aldólica cruzada com cetonas, na presença de sílicaácido sulfúrico, na ausência de solventes, tendo como produto o $\alpha, \beta$ aldólico insaturado correspondente, com excelente rendimento. $\mathrm{O}$ reagente pode ser reutilizado diversas vezes sem perda do rendimento da reação.
\end{abstract}

Aromatic aldehydes undergo crossed-aldol condensation with ketones in the presence of silica sulfuric acid under solvent-free conditions to afford the corresponding $\alpha, \beta$-unsaturated aldol products in excellent yields. The reagent is reusable for several times without any decrease in the yield of the reactions.

Keywords: crossed-aldol condensation, silica sulfuric acid, solid phase, $\alpha, \beta$-unsaturated carbonyls

\section{Introduction}

Aldol condensation is a powerful tool for the formation of carbon-carbon bond in many classes of carbonyl compounds. ${ }^{1}$ Due to the importance of methylene structural unit, which is found in many naturally occurring compounds and antibiotics, and the use of $\alpha, \alpha^{\prime}-$ bis(substituted benzylidene)cycloalkanones as precursors for the synthesis of bioactive pyrimidine derivatives, ${ }^{2}$ condensation of cycloalkanones with aldehydes and ketones is of special interest and crossed-aldol condensation is an effective pathway for these preparations. However traditional acid- or base-catalyzed reactions suffer from the reverse reaction, ${ }^{3}$ and also self-condensation of starting materials. ${ }^{4}$

Different complexes of metal ions such as $\mathrm{Mn}(\mathrm{II}), \mathrm{Fe}(\mathrm{II})$, $\mathrm{Co}(\mathrm{II}), \mathrm{Ni}(\mathrm{II}), \mathrm{Cu}(\mathrm{II})$, and $\mathrm{Zn}$ (II) with different ligands have been used for aldol condensations. ${ }^{5}$ The use of $\mathrm{Cp}_{2} \mathrm{ZrH}_{2}$ in combination with metal salts in autoclave $\left(120^{\circ} \mathrm{C}, 10 \mathrm{~h}\right)$ and under inert atmosphere have also been reported for aldol condensation of cycloalkanones. ${ }^{6}$ Bis(p-methoxyphenyl)telluroxide and $\mathrm{KF}-\mathrm{Al}_{2} \mathrm{O}_{3}$ have been used for crossed-condensation of cycloalkanones with aromatic

*e-mail: p-salehi@sbu.ac.ir aldehydes under microwave irradiation. ${ }^{6,7}$ Anhydrous $\mathrm{RuCl}_{3}$ and $\mathrm{TiCl}_{3}\left(\mathrm{SO}_{3} \mathrm{CF}_{3}\right)$ have also been used for this purpose under solvent-free conditions. ${ }^{8,9}$ The use of expensive and toxic reagents, long reaction times, low yields, and formation of a mixture of products are among the drawbacks of the reported methods. Recently, more attention has been paid to the synthesis of $\alpha, \alpha^{\prime}-$ bis(substituted benzylidene)cycloalkanones. ${ }^{10,11}$

In continuation of our studies on the application of silica sulfuric acid as a versatile and stable solid acid in organic synthesis, ${ }^{12,13}$ we wish to report an efficient and selective method for condensation of cyclic and acyclic ketones with aromatic aldehydes under solvent-free conditions.

\section{Results and Discussion}

Different types of ketones were subjected to condensation with aromatic aldehydes, containing either electron-releasing or electron-withdrawing groups, in the presence of the reagent under solvent-free conditions (Scheme 1). The results are summarized in the Table 1 . The reactions were completed within 2-3.5 h and high yields of $\alpha, \alpha^{\prime}$-bis(substituted benzylidene and cinnamylidene) cyclopentanones and cyclohexanones were obtained (entries 1-12). Under these conditions, no self-condensation of the starting materials was 
Table 1. Crossed-Aldol Condensation of Ketones with Aromatic Aldehydes in the Presence of Silica Sulfuric Acid under Solvent-free Conditions at $80{ }^{\circ} \mathrm{C}$

\begin{tabular}{|c|c|c|c|c|c|c|c|}
\hline \multirow[t]{2}{*}{ Entry } & \multirow[t]{2}{*}{ Ketone } & \multirow[t]{2}{*}{ Aldehyde } & \multirow[t]{2}{*}{ time (h) } & \multirow[t]{2}{*}{ Yield $(\%)^{\mathrm{a}}$} & \multirow[t]{2}{*}{ Product $^{\mathrm{b}}$} & \multicolumn{2}{|c|}{$\mathrm{mp}\left({ }^{\circ} \mathrm{C}\right)$} \\
\hline & & & & & & Found & Reported \\
\hline 1 & & $\mathrm{PhCHO}$ & 2.5 & 91 & & $115-118$ & $117^{6}$ \\
\hline 2 & & $4-\mathrm{Cl}-\mathrm{C}_{6} \mathrm{H}_{4} \mathrm{CHO}$ & 3 & 90 & & 146 & $147-148^{8}$ \\
\hline 3 & & 4-MeO- $\mathrm{C}_{6} \mathrm{H}_{4} \mathrm{CHO}$ & 3 & 89 & & $202-204$ & $203-204^{6}$ \\
\hline 4 & & $4-\mathrm{O}_{2} \mathrm{~N}-\mathrm{C}_{6} \mathrm{H}_{4} \mathrm{CHO}$ & 3.5 & 86 & & $160-161$ & $159^{6}$ \\
\hline 5 & & 4-Me- $\mathrm{C}_{6} \mathrm{H}_{4} \mathrm{CHO}$ & 3 & 91 & & 168 & $170^{8}$ \\
\hline 6 & & $\mathrm{PhCH}=\mathrm{CH}-\mathrm{CHO}$ & 3.5 & 86 & & $182-184$ & $180^{6}$ \\
\hline 7 & & $\mathrm{PhCHO}$ & 2 & 93 & & $190-191$ & $188-191^{6}$ \\
\hline 8 & & $4-\mathrm{Cl}-\mathrm{C}_{6} \mathrm{H}_{4} \mathrm{CHO}$ & 2.5 & 94 & & 225 & $225^{10}$ \\
\hline 9 & & $4-\mathrm{MeO}-\mathrm{C}_{6} \mathrm{H}_{4} \mathrm{CHO}$ & 2 & 95 & & $212-215$ & $210-211^{6}$ \\
\hline 10 & & $4-\mathrm{O}_{2} \mathrm{~N}-\mathrm{C}_{6} \mathrm{H}_{4} \mathrm{CHO}$ & 3 & 92 & & 230 & $230-231^{6}$ \\
\hline 11 & & $4-\mathrm{Me}-\mathrm{C}_{6} \mathrm{H}_{4} \mathrm{CHO}$ & 2.5 & 97 & & $218-219$ & $220^{10}$ \\
\hline 12 & & $\mathrm{PhCH}=\mathrm{CH}-\mathrm{CHO}$ & 2.5 & 95 & & $226-228$ & $222-224^{6}$ \\
\hline 13 & & $4-\mathrm{Cl}-\mathrm{C}_{6} \mathrm{H}_{4} \mathrm{CHO}$ & 2 & 94 & & $163-165$ & $163-165^{10}$ \\
\hline 14 & & $4-\mathrm{Me}-\mathrm{C}_{6} \mathrm{H}_{4} \mathrm{CHO}$ & 2 & 96 & & $144-145$ & $142-143^{10}$ \\
\hline 15 & $\mathrm{PhCOCH}_{3}$ & $\mathrm{PhCHO}$ & 3 & 91 & $\mathrm{Ph}-\mathrm{CH}=\mathrm{CHCOPh}$ & $55-57$ & $55-58^{14}$ \\
\hline 16 & $\mathrm{PhCOCH}_{3}$ & $4-\mathrm{Cl}-\mathrm{C}_{6} \mathrm{H}_{4} \mathrm{CHO}$ & 3 & 97 & $4-\mathrm{Cl}-\mathrm{C}_{6} \mathrm{H}_{4}-\mathrm{CH}=\mathrm{CHCOPh}$ & $109-111$ & $107-109^{10}$ \\
\hline 17 & $\mathrm{PhCOCH}_{3}$ & $4-\mathrm{MeO}-\mathrm{C}_{6} \mathrm{H}_{4} \mathrm{CHO}$ & 3 & 95 & $4-\mathrm{MeO}-\mathrm{C}_{6} \mathrm{H}_{4}-\mathrm{CH}=\mathrm{CHCOPh}$ & $74-75$ & $75-77^{14}$ \\
\hline 18 & $\mathrm{PhCOCH}_{3}$ & $4-\mathrm{Me}-\mathrm{C}_{6} \mathrm{H}_{4} \mathrm{CHO}$ & 3 & 96 & $4-\mathrm{Me}-\mathrm{C}_{6} \mathrm{H}_{4}-\mathrm{CH}=\mathrm{CHCOPh}$ & $96-97$ & $97-98^{14}$ \\
\hline 19 & & 4-Me- $\mathrm{C}_{6} \mathrm{H}_{4} \mathrm{CHO}$ & 24 & $20^{\mathrm{c}}$ & & $168-170$ & $170^{8}$ \\
\hline 20 & & $4-\mathrm{MeO}-\mathrm{C}_{6} \mathrm{H}_{4} \mathrm{CHO}$ & 24 & $10^{\mathrm{c}}$ & & $210-212$ & $210-211^{6}$ \\
\hline 21 & & $\mathrm{PhCHO}$ & 3 & $91,92,88,90^{\circ}$ & & $115-117$ & $117^{6}$ \\
\hline
\end{tabular}

${ }^{a}$ Isolated yield; ${ }^{b}$ Products were characterized by comparison of their spectroscopic data $\left({ }^{1} \mathrm{H}-\mathrm{NMR}\right.$ and IR) and mps with those reported in the literature; ${ }^{\mathrm{C}}$ The reaction was performed in the absence of the reagent; ${ }^{\mathrm{d}}$ The same reagent was used for each of the four runs. 
observed. Attempted monocondensation from one side of cycloalkanones, in the presence of lower amounts of the aldehydes, was not successful.

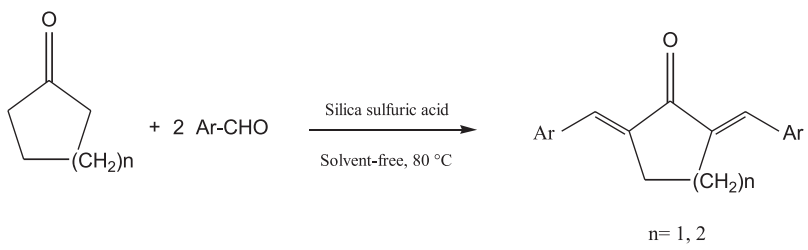

Scheme 1.

Reactions were also performed for acyclic ketones like acetophenone and 2-acetylnaphthalene and the corresponding products were obtained in excellent yields within 2-3 h (entries 13-18).

When similar reactions were conducted in different organic solvents such as acetonitrile, dichloromethane, or toluene, a mixture of products was obtained in poor yields.

The promoting effect of silica sulfuric acid in these reactions was shown by performing some reactions in the absence of the reagent (entries 19,20). Entry 21 describes the yields of four consecutive condensations of cyclohexanone and benzaldehyde. In these experiments the product was isolated and the remaining catalyst was washed and reloaded with fresh substrates for further runs. No decrease in the yield was observed, demonstrating that silica sulfuric acid can be reused in crossed-aldol condensation, without any environmental discharge.

\section{Experimental}

General

Silica sulfuric acid was prepared according to the reported procedure. ${ }^{12}$ Products were characterized by comparison of their spectroscopic data ( $\left.{ }^{1} \mathrm{HNMR}, \mathrm{IR}\right)$ and physical properties with those reported in the literature. ${ }^{6,10,14}$ All yields refer to isolated products.

General procedure for crossed-aldol condensation of ketones with aromatic aldehydes

Ketone $(2 \mathrm{mmol})$, aromatic aldehyde $(4.2 \mathrm{mmol})$ and silica sulfuric acid $\left(1.5 \mathrm{~g}\right.$, equal to $4 \mathrm{mmol}$ of $\left.\mathrm{H}^{+}\right)$were mixed thoroughly, placed in a glass tube and capped. The mixture was heated in an oven at $80{ }^{\circ} \mathrm{C}$ for $2-3.5 \mathrm{~h}$ (Table 1). After complete conversion of the ketone, as indicated by TLC, the mixture was cooled to room temperature. Dichloromethane (20-30 mL) was added and heated for few minutes. The reagent was removed by filtration. The filtrate was concentrated and the solid residue was recrystallized from ethanol to afford the pure product.
The catalyst could be recycled by washing the solid reagent remained on the filter by EtOAc $(20 \mathrm{~mL})$ followed by drying in an oven $\left(50{ }^{\circ} \mathrm{C}\right)$ for $2 \mathrm{~h}$.

\section{Conclusions}

In conclusion the present method is a very efficient and selective protocol for crossed-aldol condensation of ketones with aromatic aldehydes and high yield synthesis of $\alpha, \alpha$ '-bis(substituted benzylidene)cycloalkanones in the presence of a reusable and environmentally benign catalyst. Simple work-up procedure, including washing the mixture followed by evaporation of the solvent, is another advantage of this method.

\section{Acknowledgement}

We are grateful to Shahid Beheshti University Research Council for partial support of this work.

\section{References}

1. Smith, M. B.; March, J.; Advanced Organic Chemistry, Reactions, Mechanisms, and Structure; John Wiley \& Sons: New York, 2001, pp.1218-1224; Norcross R. D.; Paterson, I.; Chem. Rev. 1995, 95, 2041; Trost, B. M.; Fleming, I.; Comprehensive Organic Synthesis; Pergamon Press: Oxford, 1991, vol. 2, parts 1.4- 1.7; Nielsen, A. T.; Houlihan, W. J.; Org. React. 1968, 16, 1.

2. Deli, J.; Lorand, T.; Szabo, D.; Foldesi, A.; Pharmazie 1984, $39,539$.

3. Hathaway, B. A.; J. Chem. Educ. 1987, 64, 367.

4. Nakano,T.; Irifune, S.; Umano, S.; Inada, A.; Ishii, Y.; Ogawa, M.; J. Org. Chem. 1987, 52, 2239.

5. Irie, K.; Watanabe, K.; Bull. Chem. Soc. Jpn. 1980, 53, 1366.

6. Zheng, M.; Wang, L.; Shao, J.; Zhong, Q.; Synth. Commun. 1997, 27, 351 .

7. Yadav, J. S.; Subba Reddy, B. V.; Nagaraju, A.; Sarma, J. A. R. P.; Synth. Commun. 2002, 32, 893.

8. Iranpoor, N.; Kazemi, F.; Tetrahedron 1998, 54, 9475.

9. Iranpoor, N.; Zeynizadeh, B.; Aghapour, A.; J. Chem. Res. (S) 1999, 554.

10. Salehi, P.; Khodaei, M. M.; Zolfigol, M. A.; Keyvan, A.; Monatsh. Chem. 2002, 133, 1291.

11. Wang, S. X.; Li, J. T.; Geng, L. J.; J. Chem. Res. (S) 2003, 370; Deng, G. S.; Ren, T. G.; Synth. Commun. 2003, 33, 2995; Huang, D. F.; Wang, J. X.; Hu, Y. L.; Zhang, Y. M.; Tang, J.; Synth. Commun. 2002, 32, 971; Li, J. T.; Yang, W. Z.; Chen, G. F.; Li, T. S.; Synth. Commun. 2003, 33, 2619; Li, Z. F.; Zhang, Y. M.; Li, Q. L.; J. Chem. Res. (S) 2000, 580.

12. Zolfigol, M. A.; Tetrahedron 2001, 57, 9509. 
13. Zolfigol, M. A.; Bamoniri, A.; Synlett 2002, 1621; Zolfigol, M. A.; Chehardoli, G.; Mallakpour, S. E.; Synth. Commun. 2003, 33, 833; Zolfigol, M.A.; Shirini, F.; Choghamarani, A.G.; Mohammadpoor-Baltork, I.; Green Chem. 2002, 4, 562; Salehi, P.; Dabiri, M.; Zolfigol, M. A.; Bodaghi Fard, M. A.; Tetrahedron Lett. 2003, 44, 2889; Salehi, P.; Dabiri, M.; Zolfigol, M. A.; Bodaghi Fard, M. A.; Heterocycles 2003, 60, 2435.
14. Watanabe, K.; Imazawa, A.; Bull. Chem. Soc. Jpn. 1982, 55, 3208 .

Received: October 15, 2003

Published on the web: August 13, 2004 